\title{
ВИМОГИ ДО ОФОРМЛЕННЯ РУКОПИСІВ, ЩО НАПРАВЛЯЮТЬСЯ ДО ЖУРНАЛУ “БУКОВИНСЬКИЙ МЕДИЧНИЙ ВІСНИК”
}

Редакція журналу “Буковинський медичний вісник” приймає до друку рукописи, що оформлені 3 урахуванням “Сдиних вимог до рукописів, представлених у біомедичні журнали”, складених Міжнародним комітетом редакторів медичних журналів (жовтень, 2007р.) які грунтуються на сучасних підходах доказової медицини.

У журналі “Буковинський медичний вісник” публікуються статті з клінічної та експериментальної медицини, що містять нові дані. Редакція не розглядає робіт, результати яких вже опубліковані чи описані в статтях, представлені чи прийняті для опублікування в інших виданнях, як вітчизняних , так $\mathrm{i}$ зарубіжних.

При направленні статті до редакції необхідно керуватися наступними правилами:

1. Стаття має бути надрукована через 1,5 інтервала на листі формату А4 (210 X 297 мм) у двох примірниках. Розміри полів: верхнє - 20 мм, нижнє - 20 мм, ліве - 30 мм, праве - 15 мм. При наборі на комп'ютері використовується шрифт Times New Roman Cyr розміром 14 пунктів, чорного кольору, вирівнювання по ширині. Перший рядок абзацу - відступ на 15 мм. Електронна версія подається на 3,5 дюймовій дискеті (або диску CD-R/CD-RW). Редакція переконливо просить перевіряти електронну версію статті на наявність комп'ютерних вірусів.

2. Стаття візується керівником установи, до неї додається супровідний лист на бланку закладу, який направляє статтю, акт експертизи чи висновок експертної комісії, заключення про проведення біоетичної експертизи. На останній сторінці тексту повинні бути власноручні підписи всіх авторів, прізвище, ім'я, по батькові, поштова адреса, номери телефонів (службовий, мобільний, домашній) автора, з яким редакція має спілкуватися.

3. Статтю викладати за наступною схемою:

УДК

Ініціали та прізище автора (авторів)

НАЗВА СТАТТІ (ВЕЛИКИМИ ЛІТЕРАМИ)

Назва установи, де виконана робота (місто, де розташована установа). У тому випадку, якщо автори статті працюють у різних установах, необхідно 3 допомогою міток співвіднести кожного автора 3 його установою.

Резюме. Текст - мовою оригіналу статті.

Ключові слова: текст (не більше 5 слів) - мовою оригіналу статті.

Вступ. Текст.

Мета дослідження. Текст.

Матеріал і методи. Текст.

Результати дослідження та їх обговорення. Текст.

Висновки (висновок). Текст.

Перспективи подальших досліджень. Текст.

Література

НАЗВА СТАТТІ (ВЕЛИКИМИ ЛІТЕРАМИ) (АНГЛІЙСЬКОЮ МОВОЮ)

Ініціали та прізище автора(ів) (англійською мовою)

Abstract. Резюме (англійською мовою).

Key words: ключові слова (англійською мовою).

Назва установи, де виконана робота (місто, де розташована установа) (англійською мовою).

НАЗВА СТАТТІ (ВЕЛИКИМИ ЛІТЕРАМИ) (РОСІЙСЬКОЮ МОВОЮ)

Ініціали та прізище автора(ів) (російською мовою)

Резюме (російською мовою).

Ключевые слова: (російською мовою).

Назва установи, де виконана робота (місто, де розташована установа) (російською мовою).

Якщо текст статті набраний російською мовою - резюме на українській та англійській, якщо англійською - резюме на українській та російській мовах. Тексти резюме мають бути автентичними.

4. Обсяг оригінальної роботи не повинен перевищувати 9 с. машинописного тексту, заміток 3 практики 3 с., лекцій - 10 с., огляду літератури - 20 с., рецензій та хроніки - 3 с.

5. У тексті статті не потрібно повторювати дані таблиць. Для набору тексту використовувати текстовий редактор Word 97/2000/XP/2003. Набирати шрифтом Times New Roman Cyr (14) з міжрядковим інтервалом 1.5. Для формул використовувати вбудований у Word для Windows редактор формул. На диску/дискеті текст записувати окремим файлом під іменем «прізвище першого автора cmammi.doc».

6. Для набору таблиць використовувати текстовий редактор Word 97/2000/XP/2003. Потрібно слідкувати за шириною таблиці (книжковий формат - 16 см, альбомний формат - 22cм). Для заповнення таблиці користуватися кеглем 10. На диску/дискеті таблиці представити окремим файлом під іменем 
tabl.doc. Вони повинні бути компактними, мати номер (якщо таблиць 2 і більше), назву. Скорочення в назві таблиць не дозволяються. Цифровий матеріал подається із статистичною обробкою. Зазначається кількість досліджених об'єктів у кожній групі, одиниці вимірювання. Фототаблиці не приймаються.

7. Особливу увагу необхідно звернути на скорочення. Загальноприйняті абревіатури (ЕКГ, ЕЕГ, ЕМГ, УЗД, ТТГ, ЛГ, ФСГ, ІФР-1 і т.ін.) розшифровки не потребують. Способи уведення препаратів (в/в, в/м, п/ш) скорочуються. Всі інші назви при першій згадці мають розшифровуватися.

8. Обсяг графічного матеріалу має бути мінімальним. Ілюстрації не мають відтворювати дані таблиць. Всі ілюстрації виключно двовимірні, чорно-білі. Вони не повинні займати загалом більше двох сторінок. Нумеруються арабськими цифрами в порядку їх появи в тексті, наприклад, рис. 1, рис.2 і т.д. Ілюстрації подаються на окремих аркушах. На звороті ставиться підпис, прізвище автора та назва статті, позначаються «верх» $\mathrm{i}$ «низ». Фотографії повинні бути контрастними та чіткими, розміром не ширше 11 см. На електронних мікрофотографіях рекомендується показати масштабний відрізок. Електронний варіант ілюстрацій подається у форматах JPEG, TIFF, BMP, CDR, XLS. Якщо ілюстрації раніше вже публікувалися, треба вказати оригінальне джерело і представити письмовий дозвіл на їх відтворення від власника права на публікацію. Підписи до ілюстрацій необхідно подавати на окремому аркуші, вказуючи ї номери. У підписах до фотографій мікропрепаратів необхідно вказувати збільшення об'єктива та окуляра, метод забарвлення зрізів. У тексті місце таблиці й рисунка потрібно помітити стрілкою на лівому полі з позначенням над стрілкою номера таблиці або рисунка.

9. У розділі "Матеріал і методи" повинна бути ясно і чітко описана організація проведення даного дослідження (дизайн). Вказується варіант дослідження, одномоментне (поперечне), поздовжнє (проспективне або ретроспективне дослідження випадок-контроль). Повинні бути описані критерії включення в дослідження і виключення з нього (а не просто вказувати діагноз). Обов'язково зазначити наявність чи відсутність рандомізації (із вказанням методики) при розподілі пацієнтів по групах, а також про наявність чи відсутність маскування ("осліплення") при використанні плацебо і лікарського препарату в клінічних випробуваннях. У цьому розділі необхідно детально описати використану апаратуру і діагностичну техніку з вказанням їі основної технічної характеристики і виробника, а також назву комерційних наборів для гормонального і біохімічного дослідження 3 наведенням їх виробника та нормальних показників для окремих параметрів. При використанні загальноприйнятих методів дослідження на них необхідно навести відповідні посилання 3 літератури. Слід вказати точні міжнародні назви всіх використаних ліків і хімічних речовин, дози і способи використання (шляхи уведення). Якщо в статті йдеться про описання обстеження на людині, необхідно вказати, чи відповідала процедура стандартам етичного комітету, що несе відповідальність за цей фрагмент роботи, або Гельсінської декларації 1975 р. та її перегляд 1983 р. В експериментальних працях необхідно вказати вид і кількість використаних тварин, а також які застосовувалися методи знеболення та умертвіння тварин суворо відповідно до "Правил проведення робіт з використанням експериментальних тварин".

10. Опис процедури статистичного аналізу є невід’ємним компонентом розділу "Матеріал і методи". Обов'язково вказувати прийнятий у даному дослідженні критичний рівень значимості "p" (наприклад, "критичний рівень значимості при перевірці статистичних гіпотез у даному дослідженні приймали рівним 0,05"). У кожному конкретному випадку вказується фактична величина допустимого рівня значимості "p" для використаного статистичного критерію (а не просто "p $<0,05$ " або "р >0,05"). Крім того, необхідно вказати конкретні значення отриманих статистичних критеріїв (наприклад, критерій $\chi^{2}=12,3$; число ступенів свободи $d f=2, p=0,0001$ ). Необхідно дати визначення всім використаним статистичним термінам, скороченням і символічним позначенням. Наприклад: M - вибіркове середнє, m (SEM) - похибка середнього, STD - вибіркове стандартне відхилення, $\mathrm{p}$ - досягнутий рівень значимості. При використанні виразів на зразок $\mathrm{M} \pm \mathrm{m}$ необхідно вказати значення кожного із символів, а також об'єм вибірки (n). Середні величини не слід наводити точніше, ніж на один десятичний знак порівняно з вихідними даними, середньоквадратичне відхилення та похибку середнього - ще на один знак точніше. Якщо аналіз даних проводиться з використанням статистичного пакета програм, то необхідно вказати назву цього пакета і його версію.

11. Грецькі символи ( $\alpha$-, $\beta$-, $\gamma$ - тощо) слід наводити саме так, а не повною назвою букви (альфа-, бета-, гамма- тощо). Імуноглобуліни слід скорочувати латинськими символами - Ig, а не Iг або IГ; інтерлейкіни, навпаки, потрібно скорочувати українськими літерами - IЛ, а не IL, як і назви хімічних сполук (НАДФ, а не NADP, цАМФ, а не сAMP, ДНК, а не DNA тощо), за винятком тих, для яких в українській мові не існує аналогів (наприклад, фактори транскрипції, G-білки тощо). Латинські назви генів наводяться курсивом, а білків - прямим шрифтом.

12. Цитати, наведені в статті, вивіряються і на полях завіряються автором. У посиланні вказується джерело (назва, видання, рік, том, випуск, сторінка).

13. Автор повинен розмістити в статті всі формули та окремі символи. Виміри наводяться за системою CI та шкалою Цельсія. Скорочення окремих слів, термінів (крім загальноприйнятих) не допускаються. Не слід використовувати скорочення (абревіатури) в назві статті, висновках і резюме. Повний 
термін, замість якого уводиться скорочення, повинен передувати першому вживанню цього скорочення в тексті (якщо тільки це не стандартна одиниця виміру). Назви ферментів тканинних препаратів, буферів суспензійних середовищ і експериментальних методів не скорочуються. Хімічні елементи і прості неорганічні сполуки слід вказувати хімічними формулами. Назву органічних сполук можна заміняти формулами, якщо вони коротші від назви і ясно показують їх структуру. Не допускаються змішані скорочення, в яких поряд з українськими літерами входять символи атома в латинській транскрипції. У таких випадках всю абревіатуру слід писати або латинськими літерами, або українською без скорочень.

14. Список цитованої літератури наводиться за абеткою в такому порядку: 1) наукові праці, надруковані кирилицею (спочатку українською, а потім іншими мовами); 2) наукові праці, надруковані латиницею. У цій послідовності джерела літератури нумеруються. Цифрові посилання в тексті статті обов'язково повинні збігатися з відповідними номерами списку літератури. Кількість джерел у списку літератури оригінальних статей не повинна перевищувати 10-12, оглядових - 40. Посилання на неопубліковані роботи не рекомендуються. Посилання на літературу в тексті подаються номером (ами) цього джерела в списку та пишуться в квадратних дужках, наприклад, $[1,4,7]$. Список літератури повинен бути складений згідно з вимогами Державного Стандарту 7.1:2006 та вимог ВАКу України (Бюлетень ВАКу України. - 2008. - № 3. - С. 8-13). До списку літератури включаються роботи вітчизняних і зарубіжних авторів за останні 5-6 років і тільки в окремих випадках - більш ранні публікації. У лекціях бібліографічні посилання не наводяться. До таких статей додається література, рекомендована $з$ даного питання, розташована в алфавітному порядку без номерів.

15. При опублікуванні перероблених статей вказується дата поступлення переробленого примірника до редакції.

16. Редакція залишає за собою право відхиляти статті, оформлені неналежним чином, редагувати статті, а також змінювати стиль оформлення, що не впливає на зміст. Направлені в редакцію роботи не повертаються. Крім того, редакція може вимагати від автора представити вихідні дані, з використанням яких отримані наведені в статті результати.

17. Рукописи, листи, побажання і зауваження надсилайте за адресою:

58002, м. Чернівці,

пл. Театральна, 2.

Вищий державний навчальний заклад України

“Буковинський державний медичний університет"

Редакція журналу

"Буковинський медичний вісник"

Редколегія 